\title{
PENGARUH PENDAMPINGAN KADER TERHADAP PERILAKU GIZI IBU DAN STATUS GIZI BALITA
}

\author{
Mars Khendra Kusfriyadi ${ }^{1)}$,Sugiyanto ${ }^{2)}$, Fretika Utami Dewi ${ }^{3)}$ \\ ${ }^{123}$ Jurusan Gizi, Politeknik Kesehatan Palangka Raya, Jl. George Obos No.32, \\ Kota Palangka Raya,73111 \\ Email: mars_khendra@yahoo.com
}

\begin{abstract}
South Barito Regency with the problem of prevalence of malnutrition reached $30.6 \%$, the problem of short / very short and thin/very thin children was $33.6 \%$ and $18.3 \%$ respectively, far exceeding the provincial and national figures so it was necessary to get attention. Therefore, it is recommended that appropriate interventions in addressing these nutritional problems are by increasing the role of sensitive interventions and supplementary feeding. Research included quasi experiments with designs before and after intervention with comparison groups. The study was carried out in two sub-districts. Data analysis used independent t-test and Chi-square. There were significant differences between maternal behavior after cadre mentoring in the intervention group and maternal behavior in the comparison group ( $\mathrm{p}$-value $=0,000)$. There was a significant difference in behavior improvement between the intervention groups and the comparison group with ( $p$ value $=0,000)$. There are significant differences in the increase in underweight children after mentoring cadres with supplementary feeding. There is an influence of cadre assistance on maternal behavior in South Barito District. There is an influence of cadre assistance on the nutritional status of children in South Barito District.
\end{abstract}

Keywords : Cadre Mentoring, Behavior, Nutrition

\begin{abstract}
ABSTRAK
Kabupaten Barito Selatan dengan masalah prevalensi masalah gizi kurang mencapai 30,6\%, masalah anak pendek/sangat pendek dan kurus/sangat kurus berturut-turut pada angka 33,6\% dan $18,3 \%$, jauh melebihi angka provinsi dan angka nasional sehingga perlu mendapat perhatian.Oleh karena itu, direkomendasikan intervensi yang layak dilakukan dalam mengatasi permasalah gizi tersebut adalah dengan peningkatan peranan instervensi sensitif dan pemberian makanan tambahan.Penelitian termasuk quasi eksperimen dengan rancangan sebelum dan sesudah intervensi menggunakan kelompok pembanding eksternal. Analisis data menggunakan uji statistik independent samples $t$ test dan Chi-square. Terdapat perbedaan yang nyata antara perilaku ibu sesudah pendampingan kader pada kelompok intervensi dan perilaku ibu pada kelompok pembanding dengan signifikansi ( $\mathrm{p}$-value $=0,000)$. Terdapat perbedaan yang nyata peningkatan perilaku antara kelompok intervensi dengan kelompok pembanding $(\mathrm{p}$-value $=0,000)$. Terdapat perbedaan yang nyata kenaikan berat badan balita setelah pendampingan kader dengan pemberian makanan tambahan. Ada pengaruh pendampingan kader terhadap perilaku ibu di Kabupaten Barito Selatan. Ada pengaruh pendampingan kader terhadap status gizi balita di Kabupaten Barito Selatan.
\end{abstract}

Kata kunci : Pendampingan Kader, Perilaku, Gizi 
Mahakam Nursing Journal Vol 2, No. 5, Mei 2019 : 187-196

\section{PENDAHULUAN}

Anak pendek atau stunting merupakan salah satu indikator dari 3 indikator mutlak dalam menentukan Indeks Pembangunan Kesehatan Masyarakat (IPKM) yaitu prevalensi gizi kurang dan buruk, prevalensi anak kurus dan prevalensi anak pendek atau stunting (Lokakarya daerah Bermasalah Kesehatan, 2011, dalam Akhmad, dkk, 2012). Berdasarkan data terbaru tentang hasil penilaian status gizi anak balita yang dilaksanakan diseluruh provinsi di Indonesia tahun 2015 memberikan data prevalensi anak pendek/sangat pendek dan kurus/sangat kurus di Indonesia masih tinggi, yaitu $29 \%$ dan 11,9\%, sementara di Kalimantan Tengah prevalensi anak pendek/sangat pendek dan kurus/sangat kurus melebihi angka nasional berturut turut mencapai $33,4 \%$ dan $13,8 \%$ sehingga berdasarkan kriteria masalah gizi masyarakat, provinsi Kalimantan Tengah memiliki masalah gizi akut-kronis. Kabupaten Barito Selatan dengan masalah prevalensi masalah gizi kurang mencapai 30,6\%, masalah anak pendek/sangat pendek dan kurus/sangat kurus berturut-turut pada angka $33,6 \%$ dan 18,3\%, jauh melebihi angka provinsi dan angka nasional sehingga perlu mendapat perhatian.

Bukti-bukti riset menunjukkan bahwa keadaan kesehatan dan gizi anak ditentukan yang paling penting oleh peran dari ibu dalam memberikan pengasuhan dan pemberian makan, sehingga diperlukan intervensi- intervensi yang mengarah pada modifikasi perilaku kesehatan dan gizi, terutama pada ibu sebagai pemerhati utama anaknya. Dikatakan juga bahwa dalam proses perubahan perilaku terutama untuk keluarga yang jarang mengakses media massa dan berpendidikan rendah maka dapat dilakukan komunikasi antar individu yang dapat dilakukan oleh petugas kesehatan, pendidik teman sebaya atau tenaga lokal yang dilatih. Keuntungan menggunakan tenaga lokal terlatih, mereka telah terbiasa dan sensitif pada kenyataan di lingkungan sekitar termasuk dalam hal budaya. Di samping itu para peserta (keluarga) dapat lebih berempati dengan tenaga lokal lebih dari sekedar yang mereka dapat dari tenaga kesehatan profesional di fasilitas-fasilitas kesehatan.

Penelitian oleh Citrakesumasari, et al. (2006) melakukan intervensi pendampingan keluarga dan pemberian MP-ASI lokal (kuning telur) di Sulawesi Selatan, menyimpulkan bahwa pendampingan kepada ibu bayi dapat meningkatkan pengetahuan dan keterampilan ibu tentang MP-ASI sebesar $42,75 \%$. Penelitian lain yang dilakukan oleh Husaini, et al. (2001) mencoba menerapkan strategi baru penyuluhan gizi dan kesehatan dalam meningkatkan perilaku ibu selama hamil dan menyusui. Dengan melibatkan kader posyandu dan dukun bayi yang telah dilatih sebagai "Kontak Ibu" telah berhasil meningkatkan perilaku ibu secara bermakna dalam mengatasi masalah gizi dan kesehatan. 
Mahakam Nursing Journal Vol 2, No. 5, Mei 2019 : 187-196

\section{METODE PENELITIAN}

Penelitian ini merupakan penelitian quasi eksperimen dengan rancangan sebelum dan sesudah intervensi menggunakan kelompok pembanding eksternal. Subjek penelitian dibedakan menjadi 2 kelompok yaitu kelompok intervensi dan kelompok pembanding. Kelompok pembanding tidak dapat disebut kelompok kontrol sebab diperoleh tidak dengan cara randomisasi (Murti, 1997). Kelompok intervensi adalah kelompok keluarga yang terdiri dari ibu dan balita gizi kurang menurut indeks $\mathrm{BB} / \mathrm{U}$ yang mendapat pendampingan kader dengan pemberian makanan tambahan berbasis pangan lokal, sedangkan kelompok pembanding adalah kelompok keluarga yang terdiri dari ibu dan balita gizi kurang menurut indeks $\mathrm{BB} / \mathrm{U}$ namun tidak mendapat pendampingan kader dengan pemberian makanan tambahan berbasis pangan lokal.

Penelitian ini dilaksanakan di dua Kecamatan yaitu Kecamatan Dusun Selatan sebagai kelompok intervensi dan Kecamatan Gunung Bintang Awai sebagai kelompok pembanding di wilayah Kabupaten Barito Selatan. Waktu penelitian dilaksanakan pada rentang bulan Oktober hingga Desember 2016. Khusus untuk perlakukan pendampingan dilakukan mulai tanggal 1 Nopember hingga 8 Desember 2016 (10 kali kunjungan).
Sampel dipilih sesuai dengan kriteria inklusi. Adapun Kriteria Inklusi tersebut adalah : 1) Balita dengan status gizi kurang menurut indeks $\mathrm{BB} / \mathrm{U}, 2$ ) Berdomisili di lokasi penelitian, 3) Ibu balita bersedia menjadi responden. Sampel berjumlah 80 responen yaitu 40 responden pada kelompok perlakukan dan 40 responden pada kelompok pembanding.

Instrumen penelitian ini menggunakan kuesioner yang terdiri dari kuesioner karakteristik Ibu dan Balita dan kuesioner perilaku ibu. Kurikulum pelatihan kader dan buku saku kader sebagai bahan acuan dan bimbingan mandiri bagi kader dalam melakukan pendampingan. Buku saku kader berisi materi tentang : Teknis Pendampingan (tujuan, peran dan jadwal pendampingan), Komunikasi efektif, Gizi Seimbang, Keluarga Sadar Gizi (Kadarzi), Pemantauan Pertumbuhan Balita, Pengaturan Makanan Balita dan lampiran : jadwal pendampingan dan resep PMT berbasis pangan lokal

Analisis data untuk mengetahui perbedaan karakteristik antara kelompok intervensi dengan kelompok pembanding menggunakan uji statistik independent samples $t$ test (untuk data interval atau rasio) dan Chi-square (untuk data ordinal) dan untuk mengetahui perbedaan delta perubahan perilaku ibu dan delta perubahan status gizi balita pada kelompok intervensi dan kelompok pembanding digunakan uji statistik independent samples t test. 
Mahakam Nursing Journal Vol 2, No. 5, Mei 2019 : 187-196

HASIL DAN PEMBAHASAN

Tabel 1. Karakteristik Responden

Berdasarkan Umur, Pengetahuan, Sikap

dan Pendapatan Keluarga

\begin{tabular}{|c|c|c|c|c|c|}
\hline \multirow{2}{*}{$\begin{array}{c}\text { Karakteri } \\
\text { stik }\end{array}$} & \multicolumn{2}{|c|}{ Intervensi } & \multicolumn{2}{|c|}{ Pembanding } & \multirow{2}{*}{$\begin{array}{c}p \\
v a l \\
\text { ue }\end{array}$} \\
\hline & Mean & SD & Mean & SD & \\
\hline Umur & 30,5 & 5,9 & 29,95 & 6,25 & 0,68 \\
\hline $\begin{array}{l}\text { Pengetahu } \\
\text { an }\end{array}$ & 16,1 & 2,6 & 15,1 & 2,9 & 0,88 \\
\hline Sikap & 14,6 & 1,8 & 13,86 & 1,8 & 0,89 \\
\hline Pendapata & 839.0 & 540.65 & 795.62 & 324.1 & \\
\hline $\mathrm{n}$ & 00 & 5 & 5 & 30 & 0,66 \\
\hline
\end{tabular}

Berdasarkan uji independent samples $t$

test diketahui bahwa karakteristik responden pada kelompok intervensi tidak berbeda nyata dengan karakteristik responden pada kelompok pembanding, dengan nilai $p$ value $>$ 0,05 . Karakteristik responden yang meliputi pendidikan, pekerjaan ibu dan umur balita dapat dilihat pada tabel 2.

\section{Tabel 2. Karakteristik Responden}

Pendidikan, Pekerjaan Umur Balita

\begin{tabular}{|c|c|c|c|c|c|}
\hline \multirow[t]{2}{*}{ Karakteristik } & \multicolumn{2}{|c|}{ Intervensi } & \multicolumn{2}{|c|}{$\begin{array}{c}\text { Pembandi } \\
\text { ng }\end{array}$} & \multirow{2}{*}{$\begin{array}{l}\text { Sig. } \\
\text { (p) }\end{array}$} \\
\hline & n & $\%$ & $\mathbf{n}$ & $\%$ & \\
\hline \multicolumn{6}{|l|}{ Pendidikan } \\
\hline Tamat SD & 28 & 70 & 33 & 82,5 & \multirow{3}{*}{0,363} \\
\hline Tamat SLTP & 7 & 17,5 & 5 & 12,5 & \\
\hline Tamat SLTA & 5 & 12,5 & 2 & 5,0 & \\
\hline \multicolumn{6}{|l|}{ Pekerjaan } \\
\hline IRT & 34 & 85 & 32 & 80 & \multirow{3}{*}{0,545} \\
\hline Swasta & 4 & 10 & 7 & 17,5 & \\
\hline PNS & 2 & 5 & 1 & 2,5 & \\
\hline \multicolumn{6}{|l|}{ Umur Balita } \\
\hline $12-23$ bln & 13 & 32,5 & 13 & 32,5 & \multirow{3}{*}{0,394} \\
\hline $24-35$ bln & 17 & 42,5 & 12 & 30,0 & \\
\hline $36-59$ bln & 10 & 25,0 & 15 & 37,5 & \\
\hline
\end{tabular}

statistik, tidak ada perbedaan yang nyata tingkat pendidikan ibu, pekerjaan dan umur balita di kedua kelompok penelitian. Tingkat pendidikan ibu rata-rata hanya sampai pada tingkat sekolah dasar. Data ini selaras dengan data BPS Kabupaten Barito Selatan (2015),yang menyatakan bahwa persentase penduduk yang berusia 10 tahun ke atas menurut tingkat pendidikan tertinggi yang ditamatkan adalah tamat SD/MI merupakan yang terbesar yaitu 35,52\%; SLTP/MTs, 22,74 \% ; SLTA/MA, 16,58 \% dan Perguruan Tinggi (D.I, D.II, D.III, dan S.1) mencapai $2,29 \%$. Karakteritisk responden lainnya seperti status perkawinan tidak dilakukan pengujian karena semuanya telah berstatus menikah atau kawin.

Tabel 3. Rerata dan Simpangan Baku

Perilaku Responden Sebelum

Pendampingan

\begin{tabular}{rrrrr}
\hline Kelompok & n & $\begin{array}{c}\text { Rerata } \\
\text { Perilak } \\
\mathbf{u}\end{array}$ & SD & $\begin{array}{c}\boldsymbol{p} \\
\text { value }\end{array}$ \\
\hline Intervensi & 40 & 22,20 & $\pm 4,214$ & 0,521 \\
Pembanding & 40 & 21,60 & $\pm 4,113$ & \\
\hline Tabel & 3 & \multicolumn{2}{c}{ menunjukkan } & bahwa
\end{tabular}

berdasarkan uji statistik independen sample $t$ test tidak ada perbedaan yang nyata perilaku ibu sebelum pendampingan kader di kedua kelompok penelitian dengan $p$ value 0,521 ( $p$ $>0,05)$.

\section{Tabel 4. Rerata dan Simpangan Baku}

Perilaku Responden Sesudah

Pendampingan

\begin{tabular}{lcccc}
\hline \multicolumn{1}{c}{ Kelompok } & n & $\begin{array}{c}\text { Rerata } \\
\text { Perilaku }\end{array}$ & SD & $\begin{array}{c}\text { Nilai } \\
\text { p }\end{array}$ \\
\hline Intervensi & 40 & 28,525 & $\pm 3,803$ & 0,000 \\
Pembanding & 40 & 23,225 & $\pm 4,417$ & \\
\hline
\end{tabular}

Tabel 4 menunjukkan hasil uji statistik independent samples $t$ test bahwa terdapat perbedaan yang nyata antara perilaku ibu sesudah pendampingan kader pada kelompok intervensi dan perilaku ibu pada kelompok 
Mahakam Nursing Journal Vol 2, No. 5, Mei 2019 : 187-196

pembanding dengan signifikansi 0,000 (p < $0,05)$.

\section{Tabel 5. Rerata Peningkatan Perilaku}

(Delta)

\begin{tabular}{ccccc}
\hline Kelompok & n $\begin{array}{c}\text { Rerata } \\
\text { Peningkata } \\
\text { n Perilaku } \\
\text { (Delta) }\end{array}$ & SD & $\begin{array}{c}\text { Nilai } \\
\mathbf{p}\end{array}$ \\
\hline Intervensi & 40 & 6,325 & $\pm 2,005$ & 0,000 \\
Pembanding & 40 & 1.625 & $\pm 1,877$ & \\
\hline \multicolumn{4}{c}{ Tabel 5 5 menunjukkan bahwa perubahan }
\end{tabular}

perilaku gizi ibu pada kelompok intervensi lebih besar dari pada perubahan perilaku yang terjadi pada kelompok pembanding. Ini ditegaskan lagi melalui uji statistik independent samples $t$ test dengan hasil terdapat perbedaan yang nyata peningkatan perilaku antara kelompok intervensi dengan kelompok pembanding dengan nilai $p$ value $=$ $0,000(\mathrm{p}<0,05)$.

\section{Tabel 6. Rerata Kenaikan Berat Badan}

Balita Setelah Pendampingan Kader dengan Pemberian Makanan Tambahan

\begin{tabular}{|c|c|c|c|c|}
\hline Kelompok & $\mathbf{n}$ & $\begin{array}{c}\text { Rerata } \\
\text { kenaikkan } \\
\text { berat badan } \\
\text { balita (kg) }\end{array}$ & SD & $\begin{array}{c}\mathbf{p} \\
\text { value }\end{array}$ \\
\hline Intervensi & 40 & 0,415 & $\pm 0,3294$ & 0,000 \\
\hline Pembanding & 40 & 0,123 & $\pm 0,2684$ & \\
\hline
\end{tabular}

terdapat perbedaan yang nyata kenaikan berat badan balita setelah pendampingan kader dengan pemberian makanan tambahan. Sedangkan kategori status gizi balita setelah pendampingan kader dengan pemberian makanan tambahan dikedua kelompok intervensi dapat dilihat pada Tabel 7.
Tabel 7. Status Gizi Balita Setelah

Pendampingan Kader

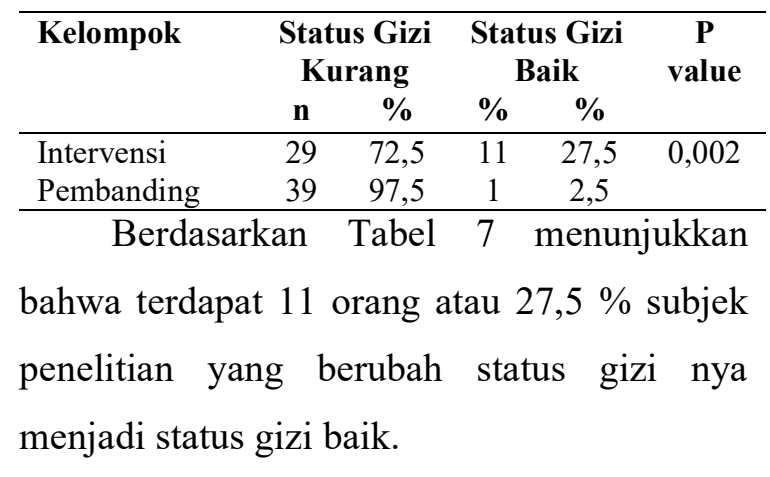

\section{Karakteristik Ibu}

Karakteristik ibu merupakan faktor luar yang tidak terkontrol sehingga dibutuhkan analisis untuk memastikan homogenitas pada kedua kelompok penelitian. Berdasarkan hasil penelitian diketahui bahwa tidak ada perbedaan yang nyata karakteristik ibu meliputi umur, pendidikan, pekerjaan, pendapatan, status perkawinan, pengetahuan dan sikap pada kelompok intervensi dan kelompok pembanding ( $\mathrm{p}$ value $>0,05$ ). Hal ini sangat menguntungkan dan membuat penelitian dapat dilanjutkan ke tahap berikutnya sehingga dapat dikatakan bahwa hasil penelitian memang karena pengaruh dari intervensi yang diberikan.

Disamping itu, beberapa karakteristik ibu juga merupakan faktor predisposisi dalam perubahan perilaku yaitu pengetahuan dan sikap. Diperkuat dengan teori dari Green, et al. (1980) bahwa faktor predisposisi merupakan faktor yang dapat mempermudah atau mempredisposisi terjadinya perilaku pada diri seseorang atau masyarakat. 
Mahakam Nursing Journal Vol 2, No. 5, Mei 2019 : 187-196

Faktor predisposisi atau pencetus antara lain adalah pengetahuan, sikap, kepercayaan, keyakinan, nilai-nilai, dan persepsi yang berhubungan dengan motivasi individu untuk berperilaku. Variabel demografi seperti sosek, umur, jenis kelamin juga merupakan faktor penting predisposisi. Seseorang yang tidak mau mengimunisasikan anaknya di posyandu dapat disebabkan karena orang tersebut tidak atau belum mengetahui manfaat imunisasi bagi anaknya.

\section{Karakteristik Balita}

Karakteristik balita yang terdiri dari umur balita merupakan faktor yang tidak terkontrol sehingga perlu dilakukan analisis terlebih dahulu. Berdasarkan uji statistik chi square diketahui bahwa tidak ada perbedaan yang nyata kategori umur balita pada kelompok intervensi dan kelompok pembanding dengan signifikansi $>0,05$. Karakteristis balita juga merupakan salah satu faktor predisposisi perubahan perilaku ibu.

\section{Perilaku Ibu Sebelum Intervensi}

Rata-rata nilai perilaku pada kelompok intervensi adalah 22,22 sedangkan rerata nilai perilaku pada kelompok pembanding sebesar 21,60. Berdasarkan hasil penelitian diketahui bahwa rerata perilaku ibu sebelum intervensi tidak berbeda nyata antara kelompok intervensi dan kelompok pembanding dengan signifikansi 0,521. Menurut Murti, 2006, bahwa dalam penelitian intervensi, kondisi sebelum diberikan perlakuan harus sebanding.

\section{Perilaku Ibu Balita Sesudah Intervensi}

Selama kurang lebih 6 minggu (10 kali kunjungan) dilakukan pendampingan keluarga oleh kader yang telah dilatih dan memiliki kemampuan dapat memberikan motivasi atau dorongan bagi keluarga untuk berperilaku hidup bersih dan sehat, memantau pertumbuhan anak, mampu membimbing dalam membuat makanan tambahan bagi anak gizi kurang dengan bahan baku berbasis pangan lokal dan memberikan bimbingan dalam pengaturan makanan keluarga dengan prinsip gizi seimbang.

Pemanfaatan kader posyandu yang aktif sebagai kader pendamping dapat memberikan nilai positif karena mereka sering dijadikan sebagai referensi bagi masyarakat sehingga perannya sebagai faktor pendorong dalam perubahan perilaku masyarakat. Hal ini senada dengan Green etal. (2000) yang menyatakan bahwa perilaku seseorang atau masyarakat tentang kesehatan ditentukan oleh faktor pendorong (reinforcing factors). Faktor pendorong (reinforcing factors) yaitu faktor yang memperkuat perubahan perilaku seseorang yang dikarenakan adanya sikap dan perilaku orang lain seperti orang tua, petugas kesehatan dan lain-lain. Petugas kesehatan yang dimaksud dalam penelitian ini adalah peran kader pendamping.

Berdasarkan hasil penelitian diketahui bahwa pendampingan kader yang dilakukan dalam penelitian ini memberikan dampak pada peningkatan skor perilaku ibu pada 
Mahakam Nursing Journal Vol 2, No. 5, Mei 2019 : 187-196

kelompok intervensi dibandingkan dengan

kelompok pembanding. Rerata skor perilaku sesudah intervensi meningkat dari 23 menjadi 29,88 atau sekitar 6 point. Sedangkan pada kelompok pembanding, peningkatan hanya 1 point saja. Sehingga secara statistik terdapat perbedaan yang bermakna skor perilaku ibu sesudah intervensi dengan nilai $p$ value 0,000 .

Menurut teori Reasoned Action atau Planned Behavior (Margetts, 2008), dijelaskan bawha orang akan bertindak apabila mereka percaya bahwa perilaku tersebut bermanfaat bagi mereka dan diterima dalam lingkungan sosial. Ada perasaan yang muncul ketika terjadi perubahan perilaku yang diakibatkan oleh desakan sosial (dari teman sebaya yang dihormatinya, media massa, dan lain-lain).

Upaya pendampingan kader terutama ditujukan dalam penyampaian informasi, dalam hal ini khusus tentang gizi. Organisasi Kesehatan Dunia (WHO) juga meyampaikan bahwa untuk memperoleh perubahan perilaku yang sesuai dengan norma-norma kesehatan dapat dilakukan dengan beberapa strategi, antara lain dengan pemberian informasi (tentang cara-cara mencapai hidup sehat, cara pemeliharaan kesehatan, cara menghindari penyakit, dan sebagainya).

\section{Perubahan Perilaku Ibu Balita Sebelum dan}

\section{Sesudah Mendapat Intervensi}

Delta skor perilaku ibu pada kelompok intervensi mengalami peningkatan 6,3 point lebih tinggi dari delta skor perilaku ibu pada kelompok pembanding (hanya 1 point).
Perbedaan tersebut bermakna secara statistik dengan nilai signifikansi 0,000. Ini menunjukkan bahwa intervensi yang diberikan memberikan dampak yang bagus bagi perubahan perilaku ibu balita khususnya mereka yang memiliki balita dengan status gizi kurang. Meskipun peningkatan perubahan perilaku hanya $15,75 \%$, hal ini dimungkinkan karena lama penelitian hanya berlangsung selama 6 minggu dengan total kunjungan 10 kali, sehingga perubahan perilaku kurang optimal.

Dalam penelitian ini metode pengumpulan data perubahan perilaku hanya mengandalkan metode recall merupakan sebuah kelemahan dalam penggalian data perubahan perilaku seseorang. Selain itu monitoring pendampingan kader yang dilakukan oleh petugas gizi puskesmas setempat juga kurang maksimal.

Proses seleksi kader pendamping yang juga masih belum begitu selektif menjadi hal yang dapat menyebabkan kurang optimalnya perubahan perilaku. Belum dilakukannya uji coba buku saku pendampingan yang dibuat oleh peneliti, merupakan faktor yang diduga mempengaruhi hasil penelitian ini. Selain itu faktor lain yang mempengaruhi perilaku yang belum diteliti dalam penelitian ini, misalnya beberapa faktor pendukung : ketersediaan sumberdaya kesehatan, keterjangkauannya, komitmen masyarakat/ pemerintah dan dukungan pengaruh media peraga promosi pendidikan kesehatan (penyuluhan), serta 
Mahakam Nursing Journal Vol 2, No. 5, Mei 2019 : 187-196

faktor pendorong yang juga dapat mempengaruhi responden untuk berubah perilakunya yaitu keluarga dari responden itu sendiri.

Namun hasil penelitian ini lebih baik daripada yang dilakukan oleh Zulkarnaini, et al. (2003), dengan intervensi pemberian pendidikan gizi pada murid SD, setelah dua minggu dapat meningkatkan perilaku ibu sebesar 11,53\%. Selain itu penelitian yang dilakukan oleh Rahmawati, et al. (2007) yang memberikan intervensi penyuluhan dengan metode modul dan media audiovisual menunjukkan bahwa pada hasil postest 3 (setelah 6 minggu) pada kelompok dengan intervensi penyuluhan dengan modul terjadi peningkatan perilaku ibu balita gizi kurang dan gizi buruk sebesar 12,27\%, sedangkan pada kelompok dengan intervensi penyuluhan dengan media audio visual mengalami peningkatan perilaku sebesar 10,45\%. Akan tetapi masih dibawah dari hasil penelitian Husaini, et al. (2000) dengan intervensi kontak ibu pada perilaku ibu hamil dan ibu bayi selama waktu 4 bulan dengan perlakuan cara I (kontak ibu dilatih selama 1 hari) dapat meningkat perilaku ibu hamil 6,4\% - 60,7 \%, sedangkan perlakuan cara II (kontak ibu dilatih 2 hari) meningkatkan perilaku ibu hamil 4,4\% - 42,9\%. Perilaku ibu bayi dengan perlakuan cara I meningkat 5,8\% - 21,3\% dan dengan perlakuan cara II perilaku ibu bayi meningkat $28,8 \%-30,9 \%$.
Meskipun demikian, penelitian ini juga memberikan dampak dan manfaat yang baik dalam peningkatan pelayanan kesehatan bagi masyarakat. Kader pendamping dapat berperan sebagai penerima keluh kesah dari masalah kesehatan masyarakat sehingga dapat menjembatani hubungan petugas kesehatan dengan masyarakatnya. Kondisi seperti akan dapat meningkatkan trust atau kepercayaan serta meningkatkan kecepatan informasi yang dapat digali dari masyarakat secara langsung. Menurut Kalita (2006), dalam penelitian nya dijelaskan bahwa pemanfaatan tenaga setempat/lokal dalam menyampaikan pesanpesan kesehatan lebih menguntungkan. Karena mereka telah menyatu dengan lingkungannya atau dengan kata lain terbiasa, sehingga pesan dapat tersampaikan secara budaya serta lebih dekat dan mengena pada keluarga sasaran.

\section{Status Gizi Balita Sebelum Intervensi}

Semua balita yang menjadi subjek dalam penelitian ini memiliki status gizi awal adalah kurang menurut indeks BB/U dengan $3<\mathrm{z}$ score $<-2$. Hal ini sengaja dilakukan untuk dapat melihat dampak dari intervensi yang dilakukan yaitu pendampingan kader dengan pemberian makanan tambahan berbasis pangan lokal. Dengan demikian tidak ada perbedaan yang nyata status gizi balita pada kelompok intervensi dan kelompok pembanding. 
Mahakam Nursing Journal Vol 2, No. 5, Mei 2019 : 187-196

\section{Status Gizi Balita Sesudah Intervensi}

Selama intervensi, kader pendamping selalu mengajak ibu balita untuk membuat makanan tambahan dengan bahan-bahan lokal yang di bawanya. Bahan pangan lokal yang menjadi bahan baku dalam pembuatan PMT tersebut adalah telur, tempe, tahu, pisang, minyak, gula, garam. Rata-rata dalam sekali penyajian makanan tambahan tersebut berkisar antara 300-400 kkal dengan 30-50 gram protein.

Semua balita dalam kelompok intervensi telah mendapat 10 kali pemberian makanan tambahan selama 6 minggu. sehingga untuk melihat dampak dari PMT tersebut diakhir masa intervensi dilakukan pengukuran berat badan kembali. Data hasil pengukuran berat badan yang dibandingkan sesuai umur balita, diketahui bahwa terdapat peningkatan berat badan dengan kisaran ratarata $0,4 \mathrm{~kg}$. Dengan demikian bahwa kenaikan berat badan tersebut diiringi dengan perubahan status gizi balita.

\section{Perubahan Status Gizi Balita Gizi Kurang} Sebelum dan Sesudah Intervensi

Berdasarkan hasil penelitian diketahui bahwa rerata kenaikan berat badan balita pada kelompok intervensi mencapai 0,4 Kg, sedangkan pada kelompok pembanding hanya $0,1 \mathrm{~kg}$ saja. Secara statistik terdapat perbedaan yang bermakna perubahan kenaikan berat badan tersebut. Hal ini berdampak pada perubahan status gizi balita yang menjadi subjek penelitian ini. Hasil penelitian membuktikan bahwa 27,5\% subjek mengalami perubahan status gizi dari status gizi kurang menjadi status gizi baik.

\section{SIMPULAN}

Berdasarkan hasil penelitian, dapat diambil kesimpulan :

1. Ada pengaruh pendampingan kader terhadap perilaku ibu di Kabupaten Barito Selatan

2. Ada pengaruh pendampingan kader terhadap status gizi balita di Kabupaten Barito Selatan.

3. Peningkatan perilaku ibu setelah mendapatkan pendampingan adalah $15,75 \%$

4. Peningkatan status gizi balita gizi kurang menjadi status gizi baik sebesar 27,5\%

\section{SARAN}

Kegiatan pendampingan kader dapat dijadikan program yang terencana dan terorganisir dengan baik sehingga memberikan dampak perubahan perilaku dan status gizi yang lebih tinggi lagi. Diperlukan uji kompetensi kader sebelum diterjunkan sebagai kader pendamping di masyarakat.

\section{UCAPAN TERIMA KASIH}

1. Direktur Poltekkes Kemenkes Palangka Raya yang telah memberi dukungan dalam penelitian ini

\section{DAFTAR PUSTAKA}

Citrakesumasari, Wahiduddin, Jafar, N., Taddaga, K., Amqam, H., Lusiana, S., 
Mahakam Nursing Journal Vol 2, No. 5, Mei 2019 : 187-196

Suarni (2006) Penanggulangan Gizi Buruk pada Bayi melalui Pendampingan dan Pemberian MP-ASI Lokal di Sulawesi Selatan. Balitbangda, Sulawesi Selatan.

Departemen Kesehatan (2005) Rencana Aksi Nasional Pencegahan dan Penanggulangan Gizi Buruk 20052009. Jakarta : Depkes RI, Direktorat Jenderal Pelayanan Kesehatan.

Departemen Kesehatan (2006) Panduan Pelatihan Kader Posyandu. Direktorat Jenderal Bina Kesehatan Masyarakat, Depkes RI, Jakarta.

Departemen Kesehatan (2007) Pedoman Pendampingan Keluarga Menuju Kadarzi. Direktorat Jenderal Bina Kesehatan Masyarakat, Direktorat Bina Gizi Masyarakat, Depkes RI, Jakarta.

Depkes RI (2008) Pedoman Respon Cepat Penanggulangan Gizi Buruk.Jakarta.

Hadi, S. (2004) Metodologi Research. Penerbit Andi, Yogyakarta.

Husaini, J.K., Widodo, Y., Salimar (2001) Strategi Baru Penyuluhan GiziKesehatan Dalam Meningkatkan Perilaku Sehat Ibu Selama Hamil dan Menyusui. Di dalam : Jurnal Penelitian Gizi dan Makanan, Volume 24. Hal: 11-23.

Kalita, A. (2006) Maternal Behaviour Change for Child Health and Nutrition. Social
Initiatives Groups, ICICI Bank, Mumbai.

Kemenkes RI (2011) Ditjen Bina Gizi dan Kesehatan Ibu dan Anak Kementerian Kesehatan. Panduan Penyelenggaraan Pemberian Makanan Tambahan Pemulihan pada Balita Gizi Kurang. Jakarta

Lemeshow, S., Hosmer Jr, D.W., Klar, J., \& Lwanga, S.K. (2007) Besar Sampel Dalam Penelitian Kesehatan. Diterjemahkan oleh Pramono, D.Gadjah Mada University Press, Yogyakarta.

Moehji, S. (1999) Ilmu Gizi. Penerbit Bhratara, Jakarta.

Murti, B. (2006) Desain dan Ukuran Sampel untuk Penelitian Kuantitatif dan Kualitatif di Bidang Kesehatan. Gadjah Mada University Press, Yogyakarta.

Notoatmodjo, S. (2007) Promosi Kesehatan dan Ilmu Perilaku.Penerbit Rineka Cipta,

Pratiknya, A.W. (2003) Dasar-dasar Metodologi Penelitian Kedokteran dan Kesehatan, Ed.1, Cet.5. PT. Raja Grafindo Persada, Jakarta.

WHO (2004) Pemberian makanan tambahan (makanan untuk anak menyusui). EGC. Jakarta 